\title{
Uji Aktivitas Analgesik Minyak Ikan pada Mencit Putih (Mus musculus) Jantan Galur BALB/c dengan Metode Writhing Test
}

\author{
Analgesic Activity of Fish Oil in BALB/c Male Mice (Mus musculus) \\ with Writhing Test Method
}

\author{
Risca Amilia, Angelica Kresnamurti, Ana Khusnul Faizah* \\ Bagian Farmasi Klinik, Prodi Farmasi, Fakultas Kedokteran, Universitas Hang Tuah, \\ Jl. Arif Rahman Hakim No. 150 Surabaya 60111, Indonesia \\ *Corresponding author email: ana.faizah@hangtuah.ac.id
}

Received 04-08-2019

Accepted 17-02-2020

Available online 01-07-2020

\begin{abstract}
ABSTRAK
Minyak ikan merupakan sumber EPA dan DHA yang berasal dari sumber daya laut. Kapsul minyak ikan merupakan salah satu nutraseutikal untuk memenuhi kebutuhan omega-3 dan omega-6. Penelitian telah dilakukan menggunakan minyak ikan salmon yang mengandung EPA dan DHA. Tujuan dari penelitian ini adalah untuk menentukan aktivitas analgesik pada tikus putih jantan (Mus musculus) strain BALB/c. Sejumlah 25 ekor tikus putih jantan dibagi menjadi 5 kelompok, masing-masing kelompok terdiri dari 5 ekor tikus putih jantan. Kelompok kontrol negatif diberi kombinasi emulsi Tween 80 dan Span 80, kelompok kontrol positif diberi aspirin, dan kelompok perlakuan diberi emulsi minyak ikan salmon dengan dosis 20, 30, dan $40 \mathrm{mg} / \mathrm{kg}$ BB. Metode yang digunakan pada penelitian ini adalah writhing test dengan menginduksi tikus putih jantan dengan asam asetat $0,6 \%$. Hasil penelitian menunjukkan bahwa emulsi minyak ikan salmon dengan dosis 20,30 , dan $40 \mathrm{mg} / \mathrm{kg}$ BB memiliki persentase hambatan nyeri masing-masing sebesar 29,44; 42,64; dan 52,59\%. Dapat disimpulkan bahwa emulsi minyak ikan salmon memiliki aktivitas analgesik.
\end{abstract}

Kata kunci: analgesik, asetosal, laut, minyak ikan salmon, nutrasetikal.

\begin{abstract}
Capsules of fish oil are the source of EPA and DHA commonly used for nutraceutical. The purpose of this research was to determine analgesic activity of salmon fish oil in white $B A L B / c$ male mice (Mus musculus). Twenty five mice were divided into 5 groups, in which each consisted of five mice. The negative control group was given emulsion of combined Tween 80 and Span 80, the positive control group was given aspirin, and three treatment groups were given Salmon fish oil emulsion at the doses of 20,30, and $40 \mathrm{mg} / \mathrm{kg} \mathrm{BW}$, respectively. The writhing test was used in this study conducted by inducing mice with
\end{abstract}


acetic acid $0.6 \%$. Pain response was characterized by legs stretching as well as the stomach attaching onto the floor. Observations were carried out for 60 minutes. The results showed that salmon fish oil emulsion in the doses of 20,30, and $40 \mathrm{mg} / \mathrm{kg} \mathrm{BB}$ exerted pain inhibitory percentages of $29.44,42.64$, and $52.59 \%$, respectively. It can be concluded that salmon fish oil emulsion have analgesic activity.

Key words: acetosal, analgesic, marine salmon fish oil, nutraceutical.

\section{Pendahuluan}

Nyeri didefinisikan sebagai pengalaman subjektif tidak menyenangkan, sensoris, emosional yang terkait dengan kerusakan jaringan (DiPiro et al., 2015). Rasa nyeri dapat diterapi dengan menggunakan analgesik berupa analgesik narkotik dan nonnarkotik. Analgesik yang sering digunakan oleh masyarakat adalah analgesik nonnarkotik golongan NSAID, salah satu contohnya adalah asetosal.

Penggunaan asetosal dapat menimbulkan efek samping pada saluran cerna seperti mual, dyspepsia, muntah, dan perdarahan saluran cerna (Sweetman, 2006). Adanya efek samping obat analgesik pada saluran cerna yang cukup tinggi menjadi salah satu alasan peneliti untuk melakukan uji aktivitas analgesik minyak ikan pada mencit. Selama ini minyak ikan hanya digunakan sebagai suplemen tambahan. Selain itu pemanfaatan biota laut dalam bidang kesehatan kurang maksimal sehingga perlu adanya eksplorasi biota laut yang menguntungkan dalam bidang kesehatan tanpa merusak ekosistem laut yang telah ada. Berdasarkan data statistika, pada tahun 2011 diketahui nilai impor Indonesia terhadap minyak ikan sebesar 4.666 ton dengan nilai nominal 17.555 juta dolar Amerika. Sedangkan nilai ekspornya sendiri adalah sebesar 183,407 ton atau setara dengan 589,132 juta dolar Amerika (Kementrian Kelautan dan Perikanan, 2012). Indonesia dikenal sebagai negara kepulauan terbanyak di dunia yang kaya akan sumber daya alam bahari. Indonesia juga dikenal sebagai salah satu negara penghasil ikan laut terbesar di dunia. Tahun 2008, Indonesia menduduki peringkat ketiga dunia setelah Cina dan Peru sebagai negara penghasil ikan laut tangkapan (FAO, 2010). Hasil tangkapan ikan di Indonesia yang tinggi dapat dimanfaatkan dalam bidang pangan dan khususnya di bidang kesehatan. Minyak ikan yang berkualitas adalah minyak ikan yang kaya akan asam lemak yang bermanfaat bagi kesehatan. Omega-3 merupakan salah satu asam lemak tak jenuh yang essensial bagi tubuh dan dibutuhkan terutama bagi penderita kolesterol tinggi. EPA dan DHA merupakan jenis omega-3 yang paling dominan pada minyak ikan. EPA dan DHA ini tidak diproduksi oleh ikan, melainkan oleh tumbuhan laut seperti alga. Kandungan EPA dan DHA dalam ikan disebabkan karena ikan tersebut mengkonsumsi alga yang mengandung 
kedua asam lemak tersebut (Haris, 2004).

Konsumsi EPA dan DHA dalam jangka waktu panjang terbukti berdampak positif terhadap penderita penyakit jantung koroner, yaitu mampu menurunkan risiko kematian mendadak hingga 45\% jika dibandingkan terhadap penderita yang tidak mengkonsumsi EPA dan DHA (Haris, 2004). EPA dan DHA juga bermanfaat terhadap penyembuhan gejala keloid (Olaitan et al., 2011). Penurunan kolesterol dalam darah khususnya LDL, antiagregasi platelet, dan antiinflamasi juga merupakan efek dari minyak ikan (Haris, 2004). Sehingga dapat dikatakan konsumsi minyak ikan secara teratur dapat meningkatkan kualitas hidup bagi penggunanya. Minyak ikan dapat bekerja menghambat jalur asam arakidonat, sehingga memberikan efek analgesik. Penelitian ini dapat memberikan gambaran apakah minyak ikan dapat digunakan sebagai analgesik. Penelitian ini bertujuan untuk mengetahui efek analgesik minyak ikan salmon dengan menggunakan metode whrithing test.

\section{Metode Penelitian}

Metode penelitian menggunakan post-test only with control group design yaitu pengukuran hanya dilakukan pada waktu tertentu setelah perlakuan pada hewan uji. Hewan uji yang digunakan adalah mencit putih jantan galur BALB/c. Besar sampel diperoleh melalui rumus Federer, yaitu:

$(\mathrm{t}-1)(\mathrm{n}-1) \geq 15$ $\mathrm{t}=$ kelompok perlakuan $=5$

$\mathrm{n}=$ jumlah sampel per kelompok perlakuan

Maka,

(5-1) $(n-1) \geq 15$

$4 n-4 \geq 15$

$\mathrm{n} \geq 5$

Total jumlah mencit yang akan digunakan pada penelitian ini adalah 25 ekor mencit jantan. Masing-masing kelompok terdiri atas 5 ekor mencit.

Teknik pengambilan sampel menggunakan metode sampling secara random (simple random sampling). Alatalat yang digunakan pada penelitian ini antara lain kandang mencit, alat-alat gelas, timbangan hewan, timbangan analitik, penangas air, jarum suntik, spuit $1 \mathrm{ml}$, sonde, dan stopwatch.

Pada penelitian ini digunakan bahan uji minyak ikan salmon yang diperoleh dari PT. X. Bahan kimia lain yang dibutuhkan dalam penelitian ini antara lain asetosal, $\mathrm{NaCl}$ fisiologis, asam asetat $0,6 \%$, akuades, tween 80 , dan span 80.

Penelitian dilaksanakan di Laboratorium Fitokimia dan Farmakologi, Program Studi Farmasi, Fakultas Kedokteran Universitas Hang Tuah Surabaya. Data yang diambil berupa respon geliat. Penelitian analgesik dengan metode writhing test digunakan waktu selama 60 menit. Penelitian menggunakan jeda waktu 30 menit untuk melihat onset obat yang memberikan efek analgesik. Respon geliat mencit diamati tiap 5 menit dengan melihat banyaknya abdomen 
mencit menyentuh lantai dan gerakan kaki depan ditarik ke depan serta gerakan kaki belakang ditarik ke belakang.

\section{Prosedur Uji Analgesik}

Pada metode ini mencit diinduksi asam asetat $0,6 \%$ secara intraperitoneal. Uji analgesik emulsi minyak ikan terhadap hewan coba dilakukan dengan tahapan sebagai berikut:

a. Mencit dipuasakan \pm 18 jam sebelum pengujian, air minum tetap diberikan.

b. Pada hari pengujian, mencit ditimbang bobotnya dan dikelompokkan secara acak menjadi 5 kelompok dengan jumlah mencit masing-masing kelompok 5 ekor mencit.

c. Pada kontrol negatif, setiap mencit diberikan emulsi tween 80 dan span 80 sebanyak 0,2 mL/20 g BB mencit secara oral dan diinduksi dengan asam asetat secara intraperitoneal.

d. Pada kontrol positif, setiap mencit diberikan asetosal dengan dosis 100 $\mathrm{mg} / \mathrm{kg}$ BB mencit secara oral dan diinduksi dengan asam asetat secara intraperitoneal.

e. Pada masing-masing kelompok perlakuan diberikan bahan uji dengan dosis yang diadopsi dari penelitian sebelumnya yaitu 20, 30, dan 40 $\mathrm{mg} / \mathrm{kg}$ BB serta diinduksi dengan asam asetat secara intraperitoneal (Faizah et al., 2019).

f. Setelah selang 5 menit jumlah geliat mencit dihitung selama 60 menit

g. Semua data yang diperoleh dianalisis secara statistika dan dihitung persentase hambatan nyeri dan $\mathrm{ED}_{50}$.

\section{Manajemen Data}

Pada penelian ini data yang didapat diolah secara statistika. Pertama dilakukan uji normalitas pada data yang didapatkan. Data dikatakan normal apabila mempunyai nilai sig>0,05. Setelah itu dilakukan uji homogenitas dan data dikatakan homogen apabila mempunyai nilai sig $>0,05$. Apabila data normal dan homogen maka dilakukan uji ANOVA, sedangkan apabila data dikatakan tidak normal dan tidak homogen maka dilakukan uji Kruskal Wallis. Selanjutnya untuk melihat adanya perbedaan antar kelompok perlakuan dilakukan uji Duncan.

\section{Hasil dan Pembahasan}

Uji Aktivitas Analgesik

Hasil pengamatan geliat pada mencit terjadi akibat pemberian asam asetat $0,6 \%$ secara intraperitoneal. Hasil geliat pada kelompok uji dibandingkan dengan kontrol negatif dan kontrol positif yaitu dengan pemberian emulsi asetosal secara oral.

Pada kontrol negatif diberi perlakuan berupa pemberian emulsi tween 80 dan span 80 secara oral. Setelah 30 menit dilakukan pemberian asam asetat $0,6 \%$ secara intraperitoneal. Hasil dari geliat mencit pada kontrol negatif selama 60 menit dapat dilihat pada Tabel 1.

Pada Tabel 1 dapat dilihat bahwa geliat mencit muncul setelah pemberian asam asetat $0,6 \%$. Pada menit ke-15 rata-rata jumlah geliat mencit mengalami peningkatan. Hal tersebut dapat dikatakan bahwa asam asetat 
0,6\% memberikan efek nyeri yang dari pemberian asam asetat $0,6 \%$ sudah maksimal pada menit ke-15. Setelah mulai berkurang. Rata-rata jumlah geliat menit ke-20 rata-rata jumlah geliat mencit mulai menurun yang berarti efek pada kontrol negatif sebesar 104,6 \pm 13,90 .

Tabel 1. Jumlah geliat mencit kelompok kontrol negatif

\begin{tabular}{|c|c|c|c|c|c|c|c|c|c|c|c|c|c|}
\hline \multirow{2}{*}{$\begin{array}{c}\text { Mencit } \\
\text { Ke- }\end{array}$} & \multicolumn{12}{|c|}{ Jumlah Geliat Menit Ke- } & \multirow{2}{*}{ Tota } \\
\hline & 5 & 10 & 15 & 20 & 25 & 30 & 35 & 40 & 45 & 50 & 55 & 60 & \\
\hline 1 & 15 & 14 & 30 & 15 & 7 & 5 & 3 & 3 & 2 & 1 & 1 & - & 96 \\
\hline 2 & 14 & 22 & 21 & 18 & 10 & 7 & 8 & 5 & 3 & 7 & 7 & 5 & 127 \\
\hline 3 & 10 & 20 & 15 & 10 & 10 & 9 & 8 & 5 & 5 & 4 & 4 & - & 100 \\
\hline 4 & 20 & 15 & 16 & 11 & 7 & 10 & 9 & 6 & 4 & 2 & 2 & 1 & 103 \\
\hline 5 & 15 & 20 & 16 & 10 & 6 & 8 & 5 & 3 & 4 & 4 & 4 & 2 & 97 \\
\hline Rata-rata & 14,8 & 18,2 & 19,6 & 12,8 & 8 & 7,8 & 6,6 & 4,4 & 3,6 & 3,6 & 3,6 & 1,6 & 104,6 \\
\hline
\end{tabular}

Pada kontrol positif diberi perlakuan berupa pemberian emulsi asetosal dengan dosis $100 \mathrm{mg} / \mathrm{kg}$ BB secara oral. Setelah 30 menit dilakukan pemberian asam asetat 0,6\% secara intraperitoneal. Hasil dari geliat mencit pada kontrol positif selama 60 menit dapat dilihat pada Tabel 2.

Tabel 2. Jumlah geliat mencit kelompok kontrol positif

\begin{tabular}{|c|c|c|c|c|c|c|c|c|c|c|c|c|c|}
\hline \multirow{2}{*}{$\begin{array}{c}\text { Mencit } \\
\text { Ke- }\end{array}$} & \multicolumn{12}{|c|}{ Jumlah Geliat Menit Ke- } & \multirow{2}{*}{ Total } \\
\hline & 5 & 10 & 15 & 20 & 25 & 30 & 35 & 40 & 45 & 50 & 55 & 60 & \\
\hline 1 & - & - & 3 & 3 & 3 & 3 & 5 & 4 & 5 & 6 & 2 & 1 & 34 \\
\hline 2 & - & - & 5 & 5 & 5 & 4 & 2 & 2 & - & - & - & 1 & 25 \\
\hline 3 & - & 1 & 2 & 2 & 2 & 9 & 6 & 5 & 4 & 2 & 2 & - & 35 \\
\hline 4 & - & 1 & 7 & 7 & 7 & 1 & 3 & 2 & 3 & 1 & - & - & 29 \\
\hline 5 & - & - & 12 & 12 & 12 & 4 & 2 & 1 & 1 & - & 1 & - & 43 \\
\hline Rata-rata & 0 & 0,4 & 5,8 & 5,6 & 5 & 4,2 & 3,6 & 2,8 & 2,6 & 1,8 & 1 & 0,4 & 33,2 \\
\hline
\end{tabular}

Tabel 2 menunjukkan bahwa geliat mencit dapat berkurang dengan adanya pemberian emulsi asetosal. Hal tersebut dapat dilihat dengan berkurangnya jumlah geliat secara signifikan dibandingkan dengan kontrol negatif. Rata-rata jumlah geliat kontrol positif sebesar $33,2 \pm 4,49$.

Kelompok perlakuan dosis I diberi emulsi minyak ikan dengan dosis $20 \mathrm{mg} / \mathrm{kg}$ BB secara oral. Setelah 30 menit dilakukan pemberian asam asetat

Tabel 3. Jumlah geliat mencit kelompok perlakuan emulsi minyak ikan dosis $20 \mathrm{mg} / \mathrm{kg}$ BB
$0,6 \%$ secara intraperitoneal. Hasil pengamatan terhadap geliat mencit pada kelompok emulsi minyak ikan pada dosis $20 \mathrm{mg} / \mathrm{kg}$ BB selama 60 menit dapat dilihat pada Tabel 3. Rata-rata jumlah geliat mencit sebesar 73,8 $\pm 8,57$ menunjukkan bahwa emulsi minyak ikan dosis $20 \mathrm{mg} / \mathrm{kg}$ BB mempunyai efek analgesik lebih rendah dari asetosal. 
PHARMACY: Jurnal Farmasi Indonesia

Vol.17 No. 01 Juli 2020:13-21

\begin{tabular}{|c|c|c|c|c|c|c|c|c|c|c|c|c|c|}
\hline \multirow{2}{*}{$\begin{array}{c}\text { Mencit } \\
\text { Ke- }\end{array}$} & \multicolumn{12}{|c|}{ Jumlah Geliat Menit Ke- } & \multirow{2}{*}{ Total } \\
\hline & 5 & 10 & 15 & 20 & 25 & 30 & 35 & 40 & 45 & 50 & 55 & 60 & \\
\hline 1 & 3 & 9 & 16 & 16 & 5 & 8 & 5 & 2 & 2 & 1 & 1 & 1 & 68 \\
\hline 2 & 8 & 11 & 19 & 16 & 6 & 6 & 3 & 2 & 1 & 2 & 1 & 1 & 72 \\
\hline 3 & 5 & 10 & 15 & 15 & 7 & 7 & 6 & 4 & 3 & 2 & 1 & 1 & 77 \\
\hline 4 & 8 & 11 & 18 & 6 & 11 & 4 & 6 & 4 & 3 & 2 & 1 & 1 & 75 \\
\hline 5 & 5 & 7 & 12 & 14 & 11 & 9 & 8 & 6 & 2 & 1 & 1 & 1 & 77 \\
\hline Rata-rata & 5,8 & 9,6 & 16 & 13,4 & 8 & 6,8 & 5,6 & 3,6 & 2,2 & 1,6 & 1 & 1 & 73,8 \\
\hline
\end{tabular}

Hasil dari geliat mencit kelompok emulsi minyak ikan dosis 30 $\mathrm{mg} / \mathrm{kg}$ BB selama 60 menit dapat dilihat pada Tabel 4. Tabel 4 menunjukkan bahwa dengan pemberian emulsi minyak ikan dosis $30 \mathrm{mg} / \mathrm{kg}$ BB dapat menurunkan frekuensi geliat mencit.
Kelompok minyak ikan dosis 30 $\mathrm{mg} / \mathrm{kg}$ BB mempunyai efek analgesik lebih rendah dibandingkan dengan asetosal. Rata-rata jumlah geliat mencit kelompok perlakuan dengan dosis emulsi minyak ikan $30 \mathrm{mg} / \mathrm{kg}$ BB sebesar $60 \pm$ 8,31 .

Tabel 4. Jumlah geliat mencit kelompok perlakuan emulsi minyak ikan dosis $30 \mathrm{mg} / \mathrm{kg} \mathrm{BB}$

\begin{tabular}{|c|c|c|c|c|c|c|c|c|c|c|c|c|c|}
\hline \multirow{2}{*}{$\begin{array}{c}\text { Mencit } \\
\text { Ke- }\end{array}$} & \multicolumn{12}{|c|}{ Jumlah Geliat Menit Ke- } & \multirow{2}{*}{ Tota } \\
\hline & 5 & 10 & 15 & 20 & 25 & 30 & 35 & 40 & 45 & 50 & 55 & 60 & \\
\hline 1 & - & 1 & 10 & 13 & 8 & 7 & 7 & 4 & 2 & 2 & 1 & - & 55 \\
\hline 2 & 3 & 12 & 11 & 11 & 5 & 6 & 6 & 4 & 2 & 2 & 2 & 1 & 65 \\
\hline 3 & - & 11 & 10 & 9 & 12 & 7 & 4 & 2 & 3 & 1 & 1 & 1 & 62 \\
\hline 4 & 3 & 12 & 10 & 8 & 7 & 5 & 5 & 5 & 1 & 1 & - & 1 & 58 \\
\hline 5 & - & 10 & 12 & 12 & 7 & 8 & 6 & 2 & 2 & - & - & 1 & 60 \\
\hline Rata-rata & 1,2 & 9,2 & 10,6 & 10,6 & 7,8 & 6,6 & 5,6 & 3,4 & 2 & 1,4 & 0,8 & 0,8 & 60 \\
\hline
\end{tabular}

Hasil dari geliat mencit dengan pemberian emulsi minyak ikan pada dosis $40 \mathrm{mg} / \mathrm{kg}$ BB selama 60 menit dapat dilihat pada tabel 5. Pada Tabel 5. dapat dilihat bahwa dengan pemberian emulsi minyak ikan dosis $40 \mathrm{mg} / \mathrm{kg}$ BB dapat menurunkan frekuensi geliat pada mencit. Hal itu dapat dilihat dari ratarata jumlah geliat mencit menurun dibandingkan dengan dosis $20 \mathrm{mg} / \mathrm{kg} \mathrm{BB}$ dan $30 \mathrm{mg} / \mathrm{kg}$ BB.

Tabel 5. Jumlah geliat mencit kelompok perlakuan emulsi minyak ikan dosis $40 \mathrm{mg} / \mathrm{kg} \mathrm{BB}$

\begin{tabular}{cccccccccccccc}
\hline $\begin{array}{c}\text { Mencit } \\
\text { Ke- }\end{array}$ & $\mathbf{1 0}$ & $\mathbf{1 0}$ & $\mathbf{1 5}$ & $\mathbf{2 0}$ & $\mathbf{2 5}$ & $\mathbf{3 0}$ & $\mathbf{3 5}$ & $\mathbf{4 0}$ & $\mathbf{4 5}$ & $\mathbf{5 0}$ & $\mathbf{5 5}$ & $\mathbf{6 0}$ & Total \\
\hline 1 & 1 & 1 & 9 & 8 & 8 & 7 & 6 & 4 & 2 & 2 & 1 & - & 49 \\
2 & 1 & 4 & 9 & 10 & 7 & 5 & 4 & 4 & 2 & 2 & 1 & 1 & 50 \\
3 & 1 & 5 & 7 & 6 & 6 & 7 & 6 & 5 & 2 & 1 & - & - & 45 \\
4 & 2 & 3 & 12 & 9 & 8 & 6 & 6 & 2 & 2 & 1 & 1 & 1 & 53 \\
5 & - & 9 & 9 & 8 & 7 & 7 & 5 & 1 & 1 & 1 & 1 & 1 & 51 \\
\hline Rata-rata & 1 & 4,4 & 9,2 & 8,2 & 7,2 & 6,4 & 5,4 & 3,2 & 1,8 & 1,4 & 0,8 & 0,6 & 49,6 \\
\hline
\end{tabular}


Data yang didapatkan berupa rata-rata jumlah geliat mencit pada kontrol positif, kontrol negatif, dan kelompok emulsi minyak ikan dengan dosis bertingkat dapat dilihat pada Gambar 1. Pada Gambar 1 dapat dilihat bahwa pemberian emulsi minyak ikan dapat mengurangi rasa nyeri pada mencit yang diakibatkan oleh pemberian asam asetat $0,6 \%$ secara intraperitoneal. Emulsi minyak ikan pada dosis 20 dan 30 $\mathrm{mg} / \mathrm{kg}$ BB memiliki aktivitas analgesik yang lebih rendah dibandingkan dengan pemberian emulsi asetosal. Sedangkan pemberian emulsi minyak ikan dengan dosis $40 \mathrm{mg} / \mathrm{kg}$ BB mempunyai efek analgesik yang hampir mendekati dengan efek analgesik yang diberikan oleh emulsi asetosal. Hal tersebut dapat dilihat dengan adanya penurunan ratarata jumlah geliat mencit selama 60 menit.
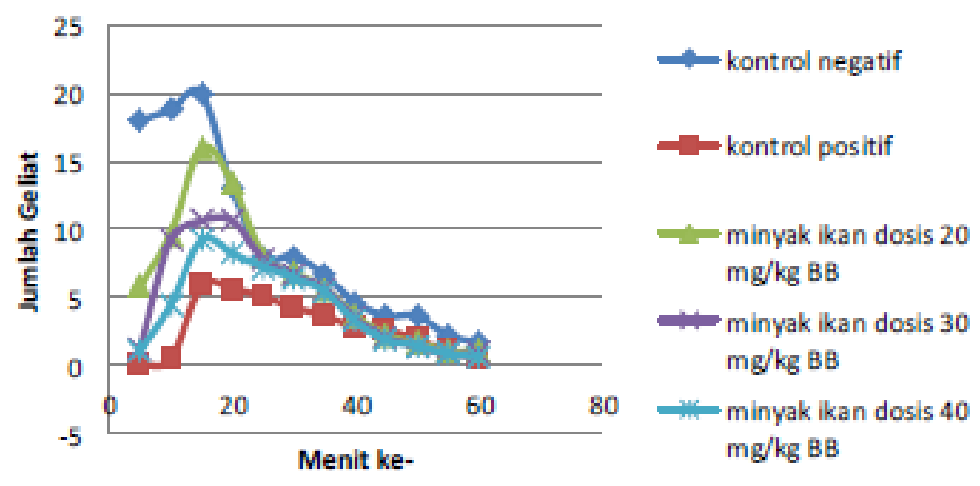

Gambar 1. Grafik geliat mencit.

\section{Persentase Hambatan Nyeri}

Persentase hambatan nyeri digunakan untuk mengetahui efektifitas pemberian emulsi minyak ikan pada mencit yang bermanfaat sebagai analgesik dibandingkan dengan pemberian emulsi asetosal. Menurut
Yayasan Pengembangan Obat Bahan Alam Phytomedica (1991) suatu bahan uji dikatakan memiliki efek analgesik jika mempunyai persentase hambatan nyeri sebesar $50 \%$ atau lebih. Persentase hambatan nyeri pada mencit dapat dilihat dalam Tabel 6.

Tabel 6. Persentase hambatan nyeri

\begin{tabular}{clc}
\hline No & Perlakuan & Persentase Hambatan Nyeri (\%) \\
\hline 1 & Kontrol Positif & 68,26 \\
2 & Minyak Ikan Dosis 20 mg/Kg BB & 29,44 \\
3 & Minyak Ikan Dosis 30 mg/Kg BB & 42,64 \\
4 & Minyak Ikan Dosis 40 mg/Kg BB & 52,59 \\
\hline
\end{tabular}


Persentase hambatan nyeri kelompok dosis $40 \mathrm{mg} / \mathrm{kg}$ BB memiliki persentase hambatan nyeri lebih dari $50 \%$ yaitu sebesar $52,59 \%$. Akan tetapi emulsi minyak ikan dosis $40 \mathrm{mg} / \mathrm{kg}$ BB belum mempunyai efek analgesik $(52,5 \%)$ sebesar kontrol positif $(68,26 \%)$.

Pada penelitian uji aktivitas analgesik yang telah dilakukan oleh Nobre menunjukkan bahwa omega-3 dengan dosis 1 ; 2,5; dan $5 \mathrm{mg} / \mathrm{kg}$ BB memiliki persentase hambatan nyeri berturut-turut sebesar 48,85 , dan $71 \%$ (Nobre, 2013). Perbedaan persentase hambatan nyeri antara penelitian yang dilakukan sekarang dengan penelitian terdahulu dikarenakan kualitas minyak ikan yang berbeda. Komposisi dan kualitas minyak ikan sangat beragam bergantung pada musim, kawasan penangkapan, jenis makanan, kematangan seksual, umur, dan jenis ikan.

Uji one-way ANOVA dilakukan untuk mengetahui perbedaan kumulatif geliat antar kelompok perlakuan. Uji one-way ANOVA menyatakan bahwa apabila nilai signifikansi $\mathrm{p}<0,05$ maka $\mathrm{HO}$ ditolak atau $\mathrm{H} 1$ diterima bila $\mathrm{p}>0,05$. Hasil penelitian ini menunjukkan bahwa nilai signifikansi sebesar 0 . Hasil penelitian ini sebanding dengan penelitian pada mencit putih yang diinduksi sehingga mengalami nyeri perifer (Faizah et al., 2019).

Hasil uji Duncan menunjukkan bahwa terdapat perbedaan bermakna antar kelompok uji dengan pemberian emulsi minyak ikan dosis bertingkat yaitu 20, 30, dan 40 mg/kg BB. Emulsi minyak ikan dengan dosis $40 \mathrm{mg} / \mathrm{kg} \quad \mathrm{BB}$ memberikan efek analgesik terbaik. Tabel 5 menunjukkan Jumlah geliat mencit total pada dosis $40 \mathrm{mg} / \mathrm{kg}$ BB memiliki nilai 49,6. Nilai tersebut menunjukkan semakin kecil rata-rata jumlah geliat mencit maka semakin poten pemberian bahan uji pada dosis tersebut.

Mekanisme kerja minyak ikan adalah dengan cara menghambat produksi mediator lipid dari asam arakhidonat. Hal ini memberikan kontribusi untuk rasa nyeri dan inflamasi (PGE 2) dan hiperalgesia (LTB 4) (Carlos, 2017).

Penelitian ini mempunyai beberapa kelemahan yaitu setiap mencit memiliki kepekaan terhadap rangsangan nyeri yang berbeda, sehingga pada saat melakukan induksi asam asetat 0,6\% secara intraperitoneal terdapat mencit yang tidak peka terhadap rangsangan nyeri yang ditimbulkan. Kelemahan kedua yaitu pada saat mencit merasakan nyeri terdapat beberapa mencit yang aktivitasnya lemah seperti mencit hanya diam di salah satu sisi pada tempat pengamatan.

\section{Simpulan}

Minyak ikan dosis $40 \mathrm{mg} / \mathrm{kg}$ BB memiliki aktivitas sebagai analgesik pada mencit putih jantan (Mus musculus) galur BALB/c.

\section{Daftar Pustaka}

Carlos, H. 2017. The use of omega-3 PUFAS in pain therapy. Journal 
of Pharmacology and Clinical Research, 3(2): ID. 555610.

DiPiro, J.T., Wells, B.G., Schwinghammer T.L., DiPiro, C.V. 2015. Pharmacotherapy Handbook. Ninth Edition. England: McGrawHill Education.

Faizah, A.K., Andhiarto, Y., Riwanti, P. 2019. In vivo analgesic activity of omega-3 on mice induced peripheral pain. Biomedical and Pharmacology Journal, 12(2): 961-963.

FAO Fisheri and Aquaculture Department. 2010. The State of World Fisheries and Aquaculture 2010. Rome: Food and Agriculture Organization of the United Nations.

Haris, W.S. 2004. Fish oil supplementation: evidence for health benefits. Cleveland Clinic Journal of Medicine. 71(3):208219.

Kementrian Kelautan dan Perikanan. 2012. Statistik Ekspor Hasil Perikanan. Jakarta: Kementrian Kelautan dan Perikanan.

Nobre, M.E.P., Correia, A.O., Borges, M.D.B., Sampaio, T.M.A., Chakraborty, S.A., Gonçalves, D.D.O., Brito, G.A.D.C., Leal., L.K.A.M., Felipe, C.F.B., Lucetti, D.L., Arida, R.M., Viana, G.S.D.B. 2013. Eicosapentaenoic acid and docosahexaenoic acid exert antiinflammatory and antinociceptive effects in rodents at low doses. Nutrition research, 33:22-433.
Olaitan, P.B., Chen, I-Ping, Norris, J.E.C. Feinn, R., Oluwatosin, O.M., Reichenberger, E.J. 2011. Inhibitory activities of omega-3 fatty acids and traditional African remedies on keloid fibroblasts. Wound, 23(4):97105.

Sweetman, S.C. 2006. Martindale. $36^{\text {th }}$ Edition. London: Pharmaceutical Press.

Yayasan Pengembangan Obat Bahan Alam Phytomedica. 1991. Penapisan Farmakologi Pengujian Fitokimia dari Pengujian Klinik. Jakarta: Yayasan Pengembangan Obat Bahan Alam Phytomedica. 